\title{
The relationship between marketing strategies and innovative market orientation on performance of halal-certified agro-food SMEs
}

\author{
${ }^{1}$ Khairuddin, N.H., ${ }^{1,3 *}$ Kamarulzaman, N.H., ${ }^{2}$ Hashim, H. and ${ }^{2}$ Hussin, S.R. \\ ${ }^{I}$ Faculty of Agriculture, Universiti Putra Malaysia, 43400 UPM Serdang, Selangor, Malaysia \\ ${ }^{2}$ Faculty of Economics and Management, Universiti Putra Malaysia 43400 UPM Serdang, Selangor, \\ Malaysia \\ ${ }^{3}$ Halal Products Research Institute, Universiti Putra Malaysia, 43400 UPM Sedang, Selangor, Malaysia
}

\begin{abstract}
Article history:
Received: 26 August 2019

Received in revised form: 24

October 2019

Accepted: 15 December 2019

Available Online: 10

February 2020
\end{abstract}

Keywords:

Marketing strategies,

Innovative market

orientation,

Halal,

Agro-food SMEs

DOI:

https://doi.org/10.26656/fr.2017.4(S1).S22

\begin{abstract}
Changes in Malaysian's lifestyle have resulted in an increased demand for trusted agrofood products. Therefore, it is becoming a challenge for halal-certified agro-food SMEs in Malaysia to fulfil the demand by implementing marketing strategies and innovative market orientation. This study aimed to investigate the relationship between marketing strategies and innovative market orientation on performance of halal-certified agro-food SMEs. A systematic random sampling was used to select 321 halal-certified agro-food SMEs located in Peninsular Malaysia and a self-administered questionnaire using a structured questionnaire was employed to obtain responses from the target SMEs. Descriptive analysis, Chi-square analysis, and Pearson correlation analysis were carried out to analyse the data. Majority of the halal-certified agro-food SMEs involved in the study were categorised as small-sized companies with at least 5 to 75 employees. The finding revealed that there was no association between annual average sales and overall performance of halal-certified agro-food SMEs. The finding further indicated that there was a strong positive relationship between the performance (market share, sales, profitability, and growth rate) of halal-certified agro-food SMEs and marketing strategies and innovative market orientation. It is suggested that the halal-certified agro-food SMEs utilize their experience to develop more effective marketing strategies for better performance.
\end{abstract}

\section{Introduction}

According to SME Corporation Malaysia, small and medium enterprises (SMEs) can be categorised based on the number of full-time employees and annual average sales of the company. Small and medium enterprises (SMEs) play an important role in the economic development of many countries including Malaysia (Sallem et al., 2017). According to Ramayah et al. (2009), SMEs contributed $99.2 \%$ to the overall business establishments in Malaysia. The share of agro-food SMEs to agricultural value-added was reported as $42.2 \%$ with manufacturing industry contributed $18.3 \%$ of the share (SME Corporation, 2016). Despite the considerable significant contribution of agro-food SMEs to the Malaysia economy, the third-quarter report of 2017 indicated more than $40 \%$ of SMEs did not perform. Financial, management, and marketing strategies are the key contributors to the failure of SMEs where they have been incompetent to sustain long enough in the marketplace (Sallem et al., 2017). Besides, the Federal
Agricultural Marketing Authority (FAMA) also reported that disorganized marketing of food SMEs as the other constraints faced by the agro-food sector (FAMA, 2015). Ahmad (2009) anticipated higher food demand in the future with the current low supply from agro-food SMEs. The author further indicated that the issue occurred was due to weaker sales and weak in marketing performance by these SMEs. Such circumstances and the volatile market have led to the domination of local food markets by imported products especially from neighbour countries like Thailand, Myanmar, and Indonesia.

Nevertheless, the changes in the Malaysian's lifestyle have resulted in an increased demand for trusted agro-food products. Rahman and Abdul (2017) described the concerns for safe and healthy food among consumers provided new avenues and opportunities for halalcertified agro-food SMEs to gain more trust and fulfil the demand for halal products. Halal certification, an indicator that is displayed by SMEs at product packaging or food premise, in form of certification, trademark or 
logo (Ab Talib et al., 2019). Many studies on halal certification were focused on consumer and less attention on processors and manufacturers especially in their market performance (Ab Talib et al., 2019; Mohamed et al., 2013; Aziz and Chok, 2013). The research on the performance of halal-certified agro-food SMEs related to marketing strategies and market orientation is lacking. However, despite the growing number of halal certification-related research, there are still lack understanding on SMEs performance especially in their marketing performance as well as branding problem that led to marketing management failure (Ab Talib et al., 2019).

According to Rahman and Abdul (2017), local SMEs tend to ignore the marketing practices on the improvement of products in relation to their business performance. In addition, these SMEs also ignored the importance of management skills in their business as they depend solely on their experience. Furthermore, Khalique et al. (2011) attributed the lack of knowledge on marketing techniques as the main problem faced by SMEs in Malaysia. Scheers (2011) further argued that inaccessibility of new ways of marketing strategy or market orientation as hindrance to the firms' success. Nevertheless, marketing concept based on basic implementation helps in business performance (Jobber and Ellis-Chadwick, 2012; Omondi, 2017). Rodriguez et al. (2014) described that the performance of SMEs can be evaluated by using financial (profitability and sales volume) or non-financial (market share and growth rate), whereas Omar et al. (2009) suggested the number of workers and business sales turnover as a measurement for performance.

Ungerman et al. (2018) also concurred that marketing strategies and market orientation are part of the marketing concepts that differed significantly from the original marketing methods. Marketing strategies were the implementation of new marketing methods that involve significant changes in product design, packaging, product placement, product promotion or pricing to increase the benefits, income, and sales (OECD, 2005; Gituma, 2017; Kanagal, 2017). Marketing strategies are an important element of development to ensure better performance of SMEs. There was a substantial association between strategy and performance at the firm (Spillan and Parnell, 2006). Few authors argued that marketing strategies namely product, price, promotion activities, and place have affected the business performance (Keskin et al., 2006; Köksal and Özgül, 2007; Haghighinasab et al., 2013). However, only two elements namely product and promotion were revealed to have impacts on marketing strategies, whereas price and distribution factors were found to have small impacts on performance. According to Sok et al. (2013), marketing strategies is one of the key contributors to SMEs' performance. This was supported by Stokes and Wilson (2010) that the impact of marketing strategies on competitive advantage and business performance would encourage SMEs to emulate marketing strategies with innovative approaches to achieve better performance.

Meanwhile, market orientation refers to the implementation of the new marketing concept which consisted of three elements namely inter-functional coordination, customer orientation, and competitor orientation (Narver and Slater, 1990; Kohli et al., 1990). However, inter-functional coordination is omitted because it is less appropriate for small-sized firms than large-scale organizations. The authors also described market orientation as the organization culture that most effectively and efficiently for continuous superior performance for the business (Narver and Slater, 1990; Kohli et al., 1990). Besides, Ozkaya et al. (2015) stated that orientation is crucially related to customers and competitors' knowledge into the company performance. Innovative market orientation is defined as the implement on innovation in market orientation along with customer orientation and competitor orientation. This was supported by Rhee et al. (2010) who indicated that innovation is importance as well as market orientation in developing better performance of SMEs. The innovative market orientation is focusing on innovation in market orientation (Lukas and Ferrell, 2000; Augusto et al., 2009). Rhee et al. (2010) concluded that market orientation has a positive impact on the innovativeness of the firm. The authors indicated that innovativeness is strongly correlated with the performance of SMEs, as the element of market orientation.

The above discussions highlight the issues regarding specific marketing strategies and innovative market orientation on the performance of halal-certified agrofood SMEs. Therefore, it is important to identify the effectiveness of marketing strategies and innovative market orientation as performance indicators for halalcertified agro-food SMEs.

In line with the above discussions, the main objective of this study was to investigate the relationship between marketing strategies and innovative market orientation on performance of halal-certified agro-food SMEs. The specific objectives of this study were: - 1) to determine the association between firmographic profiles and overall performance of halal-certified agro-food SMEs, 2) to determine the relationship between marketing strategies and performance of halal-certified agro-food SMEs, and 3) to investigate the relationship 
between innovative market orientation and performance of halal-certified agro-food SMEs.

\section{Methodology}

\subsection{Sampling and measurement}

Systematic random sampling was used to select the target halal-certified agro-food SMEs in Peninsular Malaysia. The list of potential SMEs was obtained from JAKIM (Department of Islamic Development Malaysia) Directory 2018. A total of 321 halal-certified agro-food SMEs were selected based on the recommendation by Krejcie and Morgan (1970). The data collection was carried out through a self-administered questionnaire using a structured questionnaire to obtain responses from the SMEs. The questionnaire was designed into five sections where Section A consisted of questions on socio -demographic profiles of the SMEs. Section B consisted of questions on firmographic profiles, Section C consisted of questions on marketing strategies, Section D consisted of innovative market orientation, and Section E consisted of questions on performance. Most of the questions established were closed and open-ended questions based on 5-point Likert scale statements. The questionnaires were distributed to the selected halalcertified agro-food SMEs through scheduled appointments. The respondents who involved in this study were from three different levels of job position namely top management, middle management, and lower management. As indicated by Rhee et al. (2010); Love et al. (2002), these three different levels of management could be used as a company representative who could provide their perception of company's performance. The data gathered from the survey were analysed using several statistical analyses such as descriptive analysis, Chi-square analysis, and Pearson correlation analysis.

Firstly, descriptive analysis was used to describe socio-demographic profiles (e.g. job position, age, gender, working experience, race, level of education), firmographic profiles (e.g. number of years of establishment, number of employees, annual average sales, and location), and performance status (market share, growth rate, sales, and profitability) based on the responses provided by the halal-certified agro-food SMEs. Secondly, Chi-square analysis was used to identify the association between firmographic profiles (e.g. number of years of establishment, number of employees, annual average sales, and location) and overall performance of halal-certified agro-food SMEs.

Finally, Pearson correlation analysis was carried out to identify the relationship between marketing strategies and innovative market orientation on the performance of halal-certified agro-food SMEs. The analysis determines the existence of relationships, either positive or negative, between each dimension of marketing strategies and innovative market orientation of each category of performance measured. Table 1 shows the rules of thumb used to characterize the strength of the correlation between variables (Hair et al., 2003). The strength of a relationship is indicated by the r-value listed in Table 1.

Table 1. Rules of thumb for correlation coefficient size

\begin{tabular}{ll}
\hline Coefficient Range (r) & Strength of Correlation \\
\hline 0.91 to $1.0 /-0.91$ to -1.0 & Very strong correlation \\
0.71 to $0.90 /-0.71$ to -0.90 & Strong correlation \\
0.41 to $0.70 /-0.41$ to -0.70 & Moderate correlation \\
0.21 to $0.40 /-0.21$ to -0.40 & Low correlation \\
0.01 to $0.20 /-0.01$ to -0.20 & Little if any correlation \\
\hline
\end{tabular}

Source: Hair et al. (2003)

\subsection{Conceptual framework}

Figure 1 depicts the conceptual framework of this study where independent variables consisted of firmographic profiles, marketing strategies, and innovative market orientation whereas the dependent variable consisted of the performance of halal-certified agro-food SMEs.

The following hypotheses tested in this study were: -

$H_{0}$ : Firmographic profiles have no association with the overall performance of halal-certified agro-food SMEs.

$H_{1}$ : Firmographic profiles have an association with the overall performance of halal-certified agro-food SMEs.

$H_{0}$ : There is no relationship between marketing strategies and performance of halal-certified agro-food SMEs.

$\mathrm{H}_{2}$ : There is a relationship between marketing strategies and performance of halal-certified agro-food SMEs.

$H_{0}$ : There is no relationship between innovative market orientation and performance of halal-certified agro-food SMEs.

$H_{3}$ : There is a relationship between innovative market orientation and performance of halal-certified agro-food SMEs.

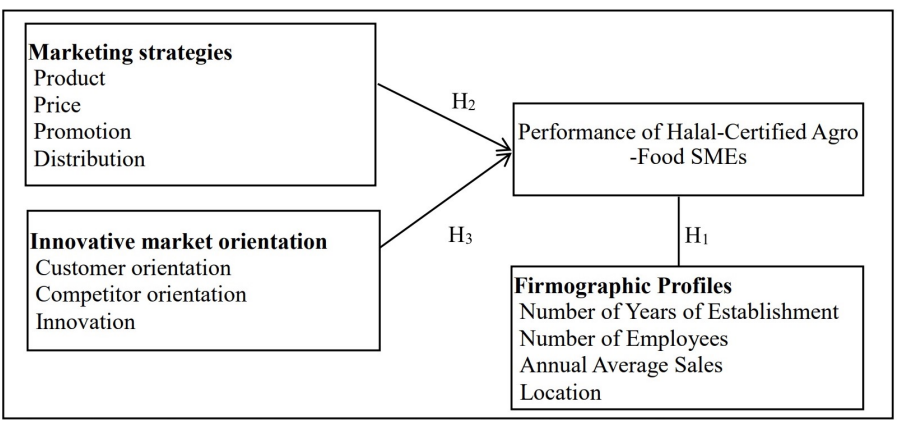

Figure 1. Conceptual framework. Source: Adapted from Keskin (2006); Rhee (2016) 


\section{Results and discussion}

\subsection{Respondents' socio-demographic profiles}

The descriptive analysis was employed to review the socio-demographic profiles of the 321 respondents of halal-certified agro-food SMEs (Table 2). In terms of position in the company, 175 respondents were from middle management $(54.5 \%)$, followed by top management with 76 respondents $(23.7 \%)$ and lower management with 70 respondents $(21.8 \%)$. Majority of the respondents, 138 respondents $(43.0 \%)$ were aged between 26 - 35 years old, followed by 72 respondents (22.4\%) of age between 36 - 45 years old. There were 63 respondents (19.6\%) aged between 36 - 45 years old and 48 respondents $(15.0 \%)$ were aged between $18-25$ years old. This indicates that minority of the respondents were of nascent entrepreneurs. Out of 321 respondents involved in the study, 137 were male $(42.7 \%)$, whereas 184 were female (57.3\%). Majority of the respondents, 113 of the respondents $(35.2 \%)$ have accumulated at least 4 - 7 years of experience in the company, followed by 95 respondents $(29.6 \%)$ with more than 12 years of working experience. There were 67 respondents $(20.9 \%)$ with working experience between $0-3$ years and the least number of the respondents, 46 respondents (14.3\%) have working experience between 8 - 11 years. The Table 2. Respondents' Socio-Demographic Profiles

\begin{tabular}{lcc}
\hline Profiles & $\begin{array}{c}\text { Frequency } \\
(\mathrm{n})\end{array}$ & $\begin{array}{c}\text { Percentage } \\
(\%)\end{array}$ \\
\hline Job Position & & \\
Top Management & 76 & 23.7 \\
Middle Management & 175 & 54.5 \\
Lower Management & 70 & 21.8 \\
\hline
\end{tabular}

Age

$18-25$ years old

$26-35$ years old

36 - 45 years old

138

$\geq 46$ years old

72

63

Gender

\begin{tabular}{lll} 
Male & 137 & 42.7 \\
Female & 184 & 57.3 \\
\hline
\end{tabular}

Working Experience

\begin{tabular}{lcc}
$0-3$ years & 67 & 20.9 \\
$4-7$ years & 113 & 35.2 \\
$8-11$ years & 46 & 14.3 \\
$\geq 12$ years & 95 & 29.6 \\
\hline
\end{tabular}

$\underline{\text { Race }}$

\begin{tabular}{lcc} 
Malay & 287 & 89.4 \\
Chinese & 17 & 5.3 \\
Indian & 13 & 4 \\
Bumiputera Sabah and Sarawak & 4 & 1.2 \\
\hline
\end{tabular}

Level of Education

SPM $84 \quad 26.2$

Diploma 28

Bachelor Degree 38.6 Master Degree 90 124 7.2 results also revealed that Malay respondents comprised as the majority with 287 respondents ( $89 \%$ ), followed by 17 Chinese respondents (5\%), 13 Indians respondents (4\%), and only 4 respondents of Bumiputera Sabah and Sarawak (1.2\%). In terms of the level of education, 124 respondents $(39 \%)$ have graduated from a bachelor's degree, followed by diploma graduates with 90 respondents $(28.0 \%)$. There were 84 respondents (26.2\%) have graduated from SPM, and only 23 respondents $(7.2 \%)$ have graduated from a master's degree.

\subsection{Firmographic profiles}

Table 3. Firmographic profiles

\begin{tabular}{lcc}
\hline Profiles & $\begin{array}{c}\text { Frequency } \\
(\mathrm{n})\end{array}$ & $\begin{array}{c}\text { Percentage } \\
(\%)\end{array}$ \\
\hline Number of Years of Establishment & & \\
$\geq 21$ years & 22 & 6.9 \\
11 - 20 years & 60 & 18.7 \\
3 - 10 years & 171 & 53.3 \\
$<3$ years & 68 & 21.2 \\
\hline
\end{tabular}

Number of Employees

$\begin{array}{lcc}5-75 \text { employees } & 231 & 72 \\ 76-200 \text { employees } & 55 & 17.1 \\ >200 \text { employees } & 35 & 10.9\end{array}$

Annual Average Sales

RM300,001 - RM500,000

RM500,001 - RM1,000,000

$113 \quad 35.2$

RM1,000,001 - RM5,000,000 $\quad 94 \quad 29.3$

$\geq$ RM5,000,001 $\quad 44 \quad 13.7$

Location

$\begin{array}{lll}\text { North } & 53 & 16.5\end{array}$

$\begin{array}{lll}\text { South } & 85 & 26.5\end{array}$

$\begin{array}{lll}\text { Centre } & 115 & 35.8\end{array}$

$\begin{array}{lll}\text { Eastern } & 68 & 21.2\end{array}$

$\mathrm{n}=321$

The descriptive analysis was employed to review the firmographic profiles of halal-certified agro-food SMEs. According to Table 3, 171 halal-certified agro-food SMEs were established between 3 - 10 years $(53.3 \%)$, followed by 68 companies established less than 3 years (21.2\%). There were 60 companies $(18.7 \%)$ established between 11 - 20 years and 22 companies (6.9\%) established for more than 21 years. Majority of the SMEs have employed at least 5 to 75 employees $(72.0 \%)$, followed by 55 companies (17.1\%) employed between 76 to 200 employees. There were 35 companies (10.9\%) with more than 200 employees. In terms of annual average sales, there were 113 companies $(35.2 \%)$ that recorded average sales between RM300,000 to RM500,000, followed by 94 companies $(29.3 \%)$ with average sales between RM1,000,001 - RM5,000,000. There were also 70 companies $(21.8 \%)$ with average 
sales of RM500,001 - RM1,000,000 and the least number of company sales was 44 companies (13.7\%) with RM5,000,001 and above. In terms of company location, 53 companies $(16.5 \%)$ were located in the North, 85 companies (26.5\%) were in the South, 115 companies (35.8\%) were in the Center and 68 companies were located in the East (21.2\%) and the Center was the highest number of responses with 115 companies $(35.8 \%)$. Table 3 summarizes the firmographic profiles.

\subsection{Performance status of halal-certified agro-food SMES}

Table 4. Halal-certified agro-food SMEs performance for past three years

\begin{tabular}{|c|c|c|}
\hline Performance & $\begin{array}{c}\text { Frequency } \\
\text { (n) }\end{array}$ & $\begin{array}{c}\text { Percentage } \\
(\%)\end{array}$ \\
\hline \multicolumn{3}{|l|}{ Market Share } \\
\hline $1 \%-20 \%$ & 75 & 23.4 \\
\hline $21 \%-40 \%$ & 91 & 28.3 \\
\hline $41 \%-60 \%$ & 72 & 22.4 \\
\hline $61 \%-80 \%$ & 58 & 18.1 \\
\hline $81 \%-100 \%$ & 25 & 7.8 \\
\hline \multicolumn{3}{|l|}{ Growth Rate } \\
\hline $1 \%-20 \%$ & 32 & 10 \\
\hline $21 \%-40 \%$ & 64 & 19.9 \\
\hline $41 \%-60 \%$ & 86 & 26.8 \\
\hline $61 \%-80 \%$ & 87 & 27.1 \\
\hline $81 \%-100 \%$ & 52 & 16.2 \\
\hline \multicolumn{3}{|l|}{$\underline{\text { Sales }}$} \\
\hline $1 \%-20 \%$ & 32 & 10 \\
\hline $21 \%-40 \%$ & 69 & 21.5 \\
\hline $41 \%-60 \%$ & 86 & 26.8 \\
\hline $61 \%-80 \%$ & 112 & 34.9 \\
\hline $81 \%-100 \%$ & 22 & 6.9 \\
\hline \multicolumn{3}{|l|}{ Profitability } \\
\hline $1 \%-20 \%$ & 74 & 23.1 \\
\hline $21 \%-40 \%$ & 87 & 27.2 \\
\hline $41 \%-60 \%$ & 88 & 27.4 \\
\hline $61 \%-80 \%$ & 54 & 16.8 \\
\hline $81 \%-100 \%$ & 18 & 5.6 \\
\hline
\end{tabular}

The descriptive analysis was employed to review the performance status of halal-certified agro-food SMEs. All 321 halal-certified agro-food SMEs agreed that their performance (market share, growth rate, sales, and profitability) has increased in the past three years (Table 4). The market share showed that out of 321 halalcertified agro-food SMEs involved in this study, 91 companies (28.3\%) have increased between $21 \%-40 \%$ for past three years, followed by 75 companies $(23.4 \%)$ have increased between $1 \%$ - 20\%, 72 companies $(22.4 \%)$ have increased between $41 \%-60 \%$ and only 58 companies (18.1\%) have increased between $61 \%-80 \%$ in their market share. The lowest market share of 25 companies (7.8\%) have increased between $81 \%$ - 100\%. In terms of growth rate, 87 companies $(27.1 \%)$ have increased between $61 \%-80 \%$, and 86 companies (26.8\%) have increased between $41 \%-60 \%$, followed by 64 companies (19.9\%) have increased between $21 \%$ $40 \%$ and 52 companies (16.2\%) have increased between $81 \%-100 \%$ in their growth rate. Meanwhile, the lowest percentage of 32 companies $(10.0 \%)$ have increased between $1 \%-20 \%$ in their growth rate.

From the annual average sales perspective, 121 companies $(34.9 \%)$ have increased between $61 \%-80 \%$ for past three years, followed by 86 companies $(26.8 \%)$ have increased between $41 \%$ - 60\%, 69 companies (21.5\%) have increased between $21 \%-40 \%$ and only 32 companies $(10.0 \%)$ have increased between $1 \%-20 \%$ of annual average sales. In terms of profitability, 88 companies (27.4\%) have increased between $41 \%-60 \%$, followed by 87 companies $(27.2 \%)$ with an increment between $21 \%$ - 40\%, 74 companies (23.1\%) have increased between $1 \%-20 \%$ and 54 companies $(16.8 \%)$ have increased between $61 \%-80 \%$. The lowest percentage of 18 companies $(5.6 \%)$ showed that their profits have increased between $81 \%-100 \%$.

\subsection{An association between firmographic profiles and overall performance of halal-certified agro-food SMEs}

Chi-square analysis was carried out to determine the association between firmographic profiles (number of years of establishment, number of employees, annual average sales, and location) and overall performance of halal-certified agro-food SMEs. Table 5 shows that three (3) firmographic profiles were found to be significantly associated with the overall performance of halal-certified agro-food SMEs at $1 \%, 5 \%$, and $10 \%$ levels of significance, respectively. First, the number of years of the establishment was significantly associated at $1 \%$ level of significance $(\mathrm{p}=0.000)$, thus the $\mathrm{H}_{0}$ was rejected. Second, number of employees was also found to be significantly associated at $5 \%$ level of significance $(\mathrm{p}=$ 0.009), thus the $\mathrm{H}_{0}$ was rejected. Next, there was an association between location and overall performance at $10 \%$ level of significance $(p=0.073)$, thus the $\mathrm{H}_{0}$ was rejected. However, the annual average sales were found to be not significant $(p=0.315)$, which indicated that there was no association between the overall performance of halal-certified agro-food SMEs and annual average sales, thus it failed to reject $\mathrm{H}_{0}$. The present finding contradicts with Akgün et al. (2007) where annual average sales were reported to be significantly associated with performance. 
Table 5. An association between firmographic profiles and overall performance of halal-certified agro-food SMEs

\begin{tabular}{lcccc}
\hline \multicolumn{1}{c}{ Variables } & Chi-square & d.f & Significant & Decision \\
\hline $\begin{array}{l}\text { Number of } \\
\text { Years of }\end{array}$ & 32.132 & 9 & $0.000 * * *$ & Reject $\mathrm{H}_{\mathrm{o}}$ \\
$\begin{array}{l}\text { Number of } \\
\text { Annual }\end{array}$ & 28.088 & 6 & $0.009 * *$ & $\begin{array}{c}\text { Reject } \mathrm{H}_{\mathrm{o}} \\
\text { Fverage Sales }\end{array}$ \\
$\begin{array}{l}\text { Location } \\
\text { Lail to }\end{array}$ \\
\hline
\end{tabular}

$* * *$ Significant at $1 \%$ level of significance, $* *$ Significant at $5 \%$ level of significance, *Significant at $10 \%$ level of significance

\subsection{Relationship between marketing strategies and performance of halal-certified agro-food SMEs}

Pearson correlation analysis was employed to measure the strength of the relationship between marketing strategies and performance of halal-certified agro-food SMEs. There were four (4) categories of performance, namely market share, sales, growth rate, and profitability. Table 6 reveals the strength of the relationships based on its r-value as indicated by the rule of thumb shown in Table 1.

There was a very strong correlation between growth rate and promotion $(\mathrm{r}=0.911, \mathrm{p}<0.01)$. Other strong relationships between two variables were between profitability and price $(\mathrm{r}=0.888, \mathrm{p}<0.01)$, market share and product $(\mathrm{r}=0.867, \mathrm{p}<0.01)$, promotion and profitability $(\mathrm{r}=0.770, \mathrm{p}<0.01)$, and sales and promotion $(\mathrm{r}=0.768, \mathrm{p}<0.01)$. There were seven (7) relationships that showed moderate correlations, namely between sales and product $(\mathrm{r}=0.685, \mathrm{p}<0.01)$, growth rate and distribution $(\mathrm{r}=0.534, \mathrm{p}<0.01)$, growth rate and price $(\mathrm{r}=0.528, \mathrm{p}<0.01)$, growth rate and product $(\mathrm{r}=0.522$, $\mathrm{p}<0.01)$, market share and promotion $(\mathrm{r}=0.515, \mathrm{p}<0.01)$, market share and price $(\mathrm{r}=0.507, \mathrm{p}<0.01)$, and sales and price $(\mathrm{r}=0.460, \mathrm{p}<0.01)$. The low correlations were between market share and distribution $(r=0.373, p<0.01)$, profitability and distribution $(\mathrm{r}=0.357, \mathrm{p}<0.01)$, and sales and distribution $(\mathrm{r}=0.329, \mathrm{p}<0.01)$. Only profitability and product $(\mathrm{r}=0.200, \mathrm{p}<0.01)$ showed a little correlation between the two variables.

Table 6 also shows that there was a positive value correlation coefficient between product, price, promotion, and distribution with each category of performance, namely market share, growth rate, sales, and profitability of halal-certified agro-food SMEs. All relationships between marketing strategies and performance of halal-certified agro-food SMEs were statistically significant with p-value less than 0.01 , indicating significant at $1 \%$ level of significance. Hence, the $\mathrm{H}_{0}$ was rejected. The present study revealed that there was a positive correlation between marketing strategies and performance of halal-certified agro-food SMEs. The highest correlation between marketing strategies and performance was promotion that has positive value correlation coefficient and a very strong correlation with the growth rate.

This result was in line with the findings by Gituma (2017) where all factors (product, price, promotion, distribution) in marketing strategies have significant relationships with firm performance. On the other hand, findings from Haghighinasab et al. (2013) showed only two factors, namely product and promotion that significantly correlated with firm performance.

\subsection{Relationship between innovative market orientation and performance of halal-certified agro-food SMEs}

Pearson correlation analysis was also carried out to measure the strength of the relationship between innovative market orientation and performance of halalcertified agro-food SMEs. There were four (4) categories of performance measured, namely market share, sales, growth rate, and profitability. Table 7 reveals the strength of the relationship based on r-value that indicates the strength of the correlation.

There was a very strong correlation between sales

Table 6. Correlation analysis between marketing strategies and performance

\begin{tabular}{|c|c|c|c|c|c|}
\hline \multicolumn{2}{|c|}{ Performance } & Product & Price & Promotion & Distribution \\
\hline \multirow[t]{3}{*}{ Market Share } & Pearson Correlation & $0.867 * * *$ & $0.507 * * *$ & $0.515 * * *$ & $0.373 * * *$ \\
\hline & Significant & 0.000 & 0.000 & 0.000 & 0.000 \\
\hline & Decision & Reject $\boldsymbol{H o}$ & Reject $\boldsymbol{H o}$ & Reject $\boldsymbol{H o}$ & Reject $\boldsymbol{H o}$ \\
\hline \multirow[t]{3}{*}{ Growth Rate } & Pearson Correlation & $0.522 * * *$ & $0.528 * * *$ & $0.901 * * *$ & $0.534 * * *$ \\
\hline & Significant & 0.000 & 0.000 & 0.000 & 0.000 \\
\hline & Decision & Reject $\boldsymbol{H o}$ & Reject $\boldsymbol{H o}$ & Reject $\boldsymbol{H o}$ & Reject $\boldsymbol{H o}$ \\
\hline \multirow[t]{3}{*}{ Sales } & Pearson Correlation & $0.685 * * *$ & $0.460^{* * *}$ & $0.768 * * *$ & $0.329 * * *$ \\
\hline & Significant & 0.000 & 0.000 & 0.000 & 0.000 \\
\hline & Decision & Reject $\boldsymbol{H o}$ & Reject $\boldsymbol{H o}$ & Reject $\boldsymbol{H o}$ & Reject $\boldsymbol{H o}$ \\
\hline \multirow[t]{3}{*}{ Profitability } & Pearson Correlation & $0.200 * * *$ & $0.888 * * *$ & $0.770 * * *$ & $0.357 * * *$ \\
\hline & Significant & 0.000 & 0.000 & 0.000 & 0.000 \\
\hline & Decision & Reject $\boldsymbol{H o}$ & Reject $\boldsymbol{H o}$ & Reject $\boldsymbol{H o}$ & Reject $\boldsymbol{H o}$ \\
\hline
\end{tabular}

$* * *$ Correlation is significant at $1 \%$ level of significance (2-tailed) 
Table 7. Correlation analysis between innovative market orientation and performance

\begin{tabular}{|c|c|c|c|c|}
\hline \multicolumn{2}{|c|}{ Performance } & Competitor Orientation & Customer Orientations & Innovation \\
\hline \multirow[t]{3}{*}{ Market Share } & Pearson Correlation & $0.366^{* * *}$ & $0.811 * * *$ & $0.441^{* * *}$ \\
\hline & Significant & 0.000 & 0.000 & 0.000 \\
\hline & Decision & Reject $\boldsymbol{H o}$ & Reject $\boldsymbol{H o}$ & Reject $\boldsymbol{H o}$ \\
\hline \multirow[t]{3}{*}{ Growth Rate } & Pearson Correlation & $0.288 * * *$ & $0.472 * * *$ & $0.802 * * *$ \\
\hline & Significant & 0.000 & 0.000 & 0.000 \\
\hline & Decision & Reject $\boldsymbol{H o}$ & Reject $\boldsymbol{H o}$ & Reject $\boldsymbol{H o}$ \\
\hline \multirow[t]{3}{*}{ Sales } & Pearson Correlation & $0.297 * * *$ & $0.537 * * *$ & $0.917 * * *$ \\
\hline & Significant & 0.000 & 0.000 & 0.000 \\
\hline & Decision & Reject $\boldsymbol{H o}$ & Reject $\boldsymbol{H o}$ & Reject $\boldsymbol{H o}$ \\
\hline \multirow[t]{3}{*}{ Profitability } & Pearson Correlation & $0.481 * * *$ & $0.304 * * *$ & $0.200 * * *$ \\
\hline & Significant & 0.000 & 0.000 & 0.000 \\
\hline & Decision & Reject $\boldsymbol{H o}$ & Reject $\boldsymbol{H o}$ & Reject $\boldsymbol{H o}$ \\
\hline
\end{tabular}

***Correlation is significant at $1 \%$ level of significance (2-tailed)

and innovation $(\mathrm{r}=0.917, \mathrm{p}<0.01)$ while the other relationships indicated strong correlations between market share and customer orientation $(\mathrm{r}=0.811, \mathrm{p}<0.01)$, and growth rate and customer orientation $(r=0.0 .802$, $\mathrm{p}<0.01$ ). There were four (4) relationships with a moderate correlation between sales and customer orientation $\quad(\mathrm{r}=0.537, \quad \mathrm{p}<0.01)$, profitability and competitor orientation $(\mathrm{r}=0.481, \mathrm{p}<0.01)$, growth rate and customer orientation $(\mathrm{r}=0.472, \mathrm{p}<0.01)$, and market share and innovation $(\mathrm{r}=0.411, \mathrm{p}<0.01)$. The low correlations were between market share and competitor orientation $(\mathrm{r}=0.366 \mathrm{p}<0.01)$, profitability and customer orientation $(\mathrm{r}=0.304, \mathrm{p}<0.01)$, profitability and customer orientation $(\mathrm{r}=0.297, \mathrm{p}<0.01)$, and growth rate and competitor orientation $(\mathrm{r}=0.288, \quad \mathrm{p}<0.01)$. Only profitability and innovation $(\mathrm{r}=0.200, \mathrm{p}<0.01)$ showed a little correlation between the two variables.

Table 7 also reveals that there was a positive value correlation coefficient between competitor orientation, customer orientation, and innovation with each category of performance measured namely market share, growth rate, sales, and profitability of halal-certified agro-food SMEs. All relationships between innovative market orientation and performance of halal-certified agro-food SMEs were statistically significant with p-value less than 0.01 , indicating significant at $1 \%$ level of significance. Hence, the $\mathrm{H}_{0}$ was rejected. The positive value of the correlation coefficient indicated that the growth rate has a very strong relationship with innovation.

The finding of this study was in line with Johnson et al. (2009); Atuahene-Gima and Wei (2011); and Ozkaya et al. (2015) who indicated that customer orientation, competitor orientation, and innovation had influenced the performance of SMEs. The finding of this study was also supported by the finding of Rhee et al. (2010) that innovation has a very strong correlation with sales, in which sales is one of the indicators of SMEs' performance.

\section{Conclusion}

The performance of halal-certified agro-food SMEs for the past three years increased based on their market share, sales, growth rate, and profitability. However, annual average sales have no association with the performance of SMEs. There were strong relationships between marketing strategies on promotion and growth rate, and between innovative market orientation on innovation and sales. This would provide some insights on how halal-certified agro-based SMEs can strengthen and enhance their marketing activities. Improvement in the promotion techniques and tools are important marketing strategies that can be developed to enhance the growth of halal-certified agro-food SMEs. Moreover, the strong relationship between innovative market orientation and sales indicates that the halal-certified agro-food SMEs should be more innovative in producing their products and thus, able to boost their business. As a conclusion, relevant marketing implementation could determine the performance of halal-certified agro-food SMEs.

\section{Acknowledgment}

We thank Universiti Putra Malaysia and Ministry of Education Malaysia (MOE) for the financial support through the Putra Grant - Putra Group Initiative (IPB); Vote No: 95422302, and the Malaysian Higher Education Consortium of Halal Institute (KIHIM) grant; Vote No: 6300912.

\section{References}

Ab Talib, M.S., Bakar, A.H.A. and Too, A.C. (2019). Conceptualizing the implementation of halal food certification: An institutional theory perspective. In Contemporary Management and Science Issues in the Halal Industry., p. 385-393. Singapore: Springer. https://doi.org/10.1007/978-981-13-2677-6_32

Ahmad, A. (2009). Marketing Practices among 
Malaysian SME's in Agro-based Industry. Persidangan Kebangsaan Ekonomi Malaysia, 2, 145 -150 .

Akgün, A.E., Keskin, H., Byrne, J.C. and Aren, S. (2007). Emotional and learning capability and their impact on product innovativeness and firm performance. Technovation, 27(9), 501-513. https:// doi.org/10.1016/j.technovation.2007.03.001

Atuahene-Gima, K. and Wei, Y. (2011). The vital role of problem-solving competence in new product success. Journal of Product Innovation Management, 28(1), 81-98. https://doi.org/10.1111/ j.1540-5885.2010.00782.x

Augusto, M. and Coelho, F. (2009). Market orientation and new-to-the-world products: Exploring the moderating effects of innovativeness, competitive strength, and environmental forces. Industrial Marketing Management, 38(1), 94-108. https:// doi.org/10.1016/j.indmarman.2007.09.007

Aziz, Y.A. and Chok, N.V. (2013). The role of Halal awareness, Halal certification, and marketing components in determining Halal purchase intention among non-Muslims in Malaysia: A structural equation modelling approach. Journal of International Food and Agribusiness Marketing, 25 (1), 1-23. https:// doi.org/10.1080/08974438.2013.723997

Gituma, M.M. (2017). Effects of Marketing Mix on Sales Performance: A Case of Unga Feeds Limited. Nairobi, Kenya: United States International University-Africa, $\mathrm{PhD}$ Dissertation.

Haghighinasab, M., Sattari, B., Ebrahimi, M. and Roghanian, P. (2013). Identification of Innovative Marketing Strategies to Increase the Performance of SMEs in Iran. International Journal of Fundamental Psychology and Social Sciences, 3(2), 26-30.

Hair, J.F., Celsi, M., Ortinau, D.J. and Bush, R.P. (2008). Essentials of Marketing Research. New York, NY: McGraw-Hill/Higher Education.

Johnson, A.J., Dibrell, C.C. and Hansen, E. (2009). Market orientation, innovativeness, and performance of food companies. Journal of Agribusiness, 27, 85106.

Kanagal, N.B. (2017). Role of relationship marketing in a competitive marketing strategy. Journal of Management and Marketing Research, 2, 1-17.

Keskin, H. (2006). Market orientation, learning orientation, and innovation capabilities in SMEs: An extended model. European Journal of Innovation Management, 9(4), 396-417. https:// doi.org/10.1108/14601060610707849

Khalique, M., Isa, A.H.M., Shaari, J.A.N. and Ageel, A.
(2011). Challenges faced by the small and medium enterprises (SMEs) in Malaysia: An intellectual capital perspective. International Journal of Current Research, 3(6), 398-401.

Kohli, A.K. and Jaworski, B.J. (1990). Market orientation: the construct, research propositions, and managerial implications. Journal of Marketing, 54 (2), 1-18. https:// doi.org/10.1177/002224299005400201

Köksal, M.H. and Özgül, E. (2007). The relationship between marketing strategies and performance in an economic crisis. Marketing Intelligence and Planning, 25(4), 326-342. https:// doi.org/10.1108/02634500710754574

Krejcie, R.V. and Morgan, D.W. (1970). Determining sample size for research activities. Educational and Physiological Measurement, 30(3), 607-610. https:// doi.org/10.1177/001316447003000308

Love, L.G., Priem, R.L. and Lumpkin, G.T. (2002). Explicitly articulated strategy and firm performance under alternative levels of centralization. Journal of Management, 28(5), 611-627. https:// doi.org/10.1177/014920630202800503

Lukas, B.A. and Ferrell, O.C. (2000). The effect of market orientation on product innovation. Journal of the Academy of Marketing Science, 28(2), 239-247. https://doi.org/10.1177/0092070300282005

Mohamed, Z., Shamsudin, M.N. and Rezai, G. (2013). The effect of possessing information about halal logo on consumer confidence in Malaysia. Journal of International Food and Agribusiness Marketing, 25 (Suppl. 1), 73-86. 1ttps:// doi.org/10.1080/08974438.2013.800008

Narver, J.C. and Slater, S.F. (1990). The effect of a market orientation on business profitability. Journal of Marketing, 54(4), 20-35. https:// doi.org/10.1177/002224299005400403

Omondi, O.J. (2017). Impact of Digital Marketing on Sales Growth of Small and Medium Enterprises in Nairobi, Kenya. Nairobi, Kenya: University of Nairobi, PhD Dissertation.

Omar, S.S., Arokiasamy, L. and Ismail, M. (2009). The Background and Challenges Faced by the Small Medium Enterprises. A Human Resource Development Perspective. International Journal of Business and Management, 4(10), 95-102. https:// doi.org/10.5539/ijbm.v4n10p95

Ozkaya, H.E., Droge, C., Hult, G.T.M., Calantone, R. and Ozkaya, E. (2015). Market orientation, knowledge competence, and innovation. International Journal of Research in Marketing, 32 (3), 309-318. https://doi.org/10.1016/ 
j.ijresmar.2014.10.004

Rahman, A. and Abdul, M. (2017). Establishment of traceability practices through halal assurance system (HAS) implementation. International Journal of Academic Research in Business and Social Sciences, 7, 130-139. https://doi.org/10.6007/IJARBSS/v7i6/2951

Ramayah, T., Mohamad, O., Omar, A. and Marimuthu, M. (2009). Technology adoption among small and medium enterprises (SMEs): A research agenda. World Academy of Science, Engineering and Technology, 53, 943-946.

Rhee, J., Park, T. and Lee, D.H. (2010). Drivers of innovativeness and performance for innovative SMEs in South Korea: Mediation of learning orientation. Technovation, 30(1), 65-75. https:// doi.org/10.1016/j.technovation.2009.04.008

Rodriguez, M., Peterson, R.M. and Ajjan, H. (2015). CRM/social media technology: impact on customer orientation process and organizational sales performance. In Ideas in Marketing: Finding the New and Polishing the Old., p. 636-638. USA: Springer, Cham. https://doi.org/10.1007/978-3-31910951-0_233

Sallem, N.R.M., Nasir, N.E.M., Nori, W.M.N.W.M. and Kassim, C.K.H.C.K. (2017). Small and medium enterprises: Critical problems and possible solutions. International Business Management, 11 (1), 47-52.

Scheers, L.V. (2011). SMEs marketing skills challenges in South Africa. African Journal of Business Management, 5(13), 5048-5056.

Sok, P., O’Cass, A. and Sok, K.M. (2013). Achieving superior SME performance: Overarching role of marketing, innovation, and learning capabilities. Australasian Marketing Journal, 21(3), 161-167. https://doi.org/10.1016/ j.ausmj.2013.04.001

Spillan, J. and Parnell, J. (2006). Marketing resources and firm performance among SMEs. European Management Journal, 24(2-3), 236-245. https:// doi.org/10.1016/j.emj.2006.03.013

Stokes, D. and Wilson, N. (2010). Small business management and entrepreneurship. UK: Cengage Learning EMEA.

Ungerman, O., Dedkova, J. and Gurinova, K. (2018). The impact of marketing innovation on the competitiveness of enterprises in the context of industry 4.0. Journal of Competitiveness, 10(2), 132148. https://doi.org/10.7441/joc.2018.02.09 